\title{
Service Quality, Company Image and Location Affect to Customer Loyalty Case of: Bank Jatim Main Branch Surabaya
}

\author{
Amin Mahmudi AS, Ani Wulandari, Arasy Alimudin \\ Departement of Management, Narotama University Surabaya \\ Jl. Arif Rachman Hakim 51, Surabaya 60117 Indonesia/Telp 031-5946404/Fax. 031-5931213 \\ amin.mahmudi922a@gmail.com, ani.wulandari@narotama.ac.id, \\ arasy.alimudin@narotama.ac.id
}

\begin{abstract}
This study aims to determine the effect of the variables of Service Quality, Company Image and Location on Customer Loyalty at Bank Jatim Main Branch Surabaya. This research was conducted with quantitative methods. The data studied are primary data obtained directly from the company in the form of questionnaire results with a sample of 100 respondents from bank Jatim customers, the main branch of Surabaya and analyzed using SPSS version 25 for windows. The data were tested using the classical assumption test, namely: normality, multicollinearity, and heteroscedasticity. Then tested using $t$ test, $\mathrm{f}$ test and determination test $\mathrm{R}^{2}$. The results showed that the variables of Service Quality, Company Image, and Location partially had a significant positive effect. Simultaneously seen from the test results, the F value of 15,889 with a value of sig $=0.000$ shows that it is smaller than the value of $=0.050(0.000<0.050)$ which means that the service quality variable (X1), company image (X2), location (X3) simultaneously significant effect on Service Quality.
\end{abstract}

Keywords: Company Image and Location on Customer Loyalty, Service Quality

\section{Introduction}

Bank is a business entity that collects funds from the public in the form of savings and distributes it to the public in the form of credit and/or other forms in order to improve the people's standard of living. Broadly speaking, banking can be interpreted as a company engaged in financial services that accommodates funds in the form of savings and then distributed them in the form of credit. According to Law No. 10 of 1998 dated November 10, 1998 concerning banking, it can be concluded that the banking business includes three activities, namely collecting funds, distributing funds, and providing other bank services. The main function of Indonesian banking is as a collector and distributor of public funds and aims to support the implementation of national development in the context of increasing equitable distribution of development and its results, economic growth and national stability, towards increasing the standard of living of the people.

Based on the description of the background problems and phenomena that occurred above as well as the results of different previous studies, the researchers are interested in re-examining the variables that affect customer loyalty at Bank Jatim Main Branch Surabaya, namely "The Effect of Service Quality, Company Image, and Location on Customer Loyalty. (case study at Bank Jatim Surabaya Main Branch). as follows:

In this study, the author uses a theoretical review according to several experts, the theoretical review is

\subsection{Problem Formulation}

a. Can service quality affect customer loyalty?

b. Can company image affect customer loyalty?

c. Can a strategic location affect customer loyalty?

d. Do the variables of service quality, company image, and location simultaneously have a significant effect on customer loyalty?

\subsection{Research Objectivies}

The aims of this research are as follows:

a. Knowing the effect of service quality on customer loyalty at Bank Jatim Main Branch Surabaya.

b. Knowing the effect of corporate image on customer loyalty at Bank Jatim Main Branch Surabaya.

c. Knowing the influence of location factors on customer loyalty at Bank Jatim Main Branch Surabaya

d. Knowing the simultaneous effect of these three variables on customer loyalty at Bank Jatim Main Branch Surabaya.

e. Knowing the partial effect of the three variables on customer loyalty at Bank Jatim Main Branch Surabaya. 


\section{JURNAL EKONOMI}

\subsection{Research Benefits}

\section{a. Theoretical benefits}

For researchers, it is a new insight obtained regarding the influence of service quality, company image, and location on customer loyalty so that the knowledge gained in lectures is very useful in this study.

b. Practical benefits

This research is expected to be useful documentation for academic activities so that it can be used as well as possible and the results in this study can be used as library references.

c. Share Banking

The researcher's priority is to improve service quality, company image and location as well as several things that can increase customer loyalty.

\section{Literature Review}

\subsection{Literature Review}

\section{a. Service quality}

Service quality is defined as the act or deed of a person or organization aimed at providing satisfaction to customers or employees (Kasmir, 2017b:47). In general, the quality of service is a performance offered by someone to another person to meet their needs. (Yolanda \& Firdaus, 2019)

\section{b. Company image}

Kotler \& Keller (2014) in (Mutmainnah, 2018) reveal that the image is the impression a person feels about an object or item or the organization as a whole which will then be stored in the consumer's memory. (Batin, 2020)

\section{c. Location}

According to Swastha in Dulkhatif et al., (2016) that the location (place) displays various activities of a company with the aim that the company's products can be available and obtained by consumers later.(Sharah et al., 2021)

\section{d. Customer loyalty}

Loyalty is more aimed at a behavior, which is indicated by routine purchases and is based on a decision-making unit. (Sangadji and Sopiah, 2013: 105). (Zulkarnain, 2020)

\subsection{Empirical Review}

1. Research conducted by Abdul Razak, Jusbair Baheri, and Muhammad Irsyad Ramadhan: 2018 with the title "The Effect of Satisfaction and Trust on Customer Loyalty at Bank Negara Indonesia (BNI) Kendari Branch". The results showed that: (1). Simultaneously, satisfaction and trust have a positive and significant impact on customer loyalty, (2). Some satisfaction has a positive and not significant effect on customer loyalty and (3). Partially trust has a positive and significant impact on customer loyalty.(RAZAK, 2018)

2. Research journal by Rizal Zulkarnain, HER Taufik, Agus David Ramdansyah: 2020 at the Faculty of Economics and Business, University of Banten Jaya-Serang City with the title "The Effect of Service Quality and Product Quality on Customer Loyalty with Customer Satisfaction as an Intervening Variable (Case Study at PT Bank Syariah Mu'amalah Cilegon)". Based on the results of the study indicate that service quality has a positive and significant effect on customer loyalty, product quality has a positive and significant effect on customer loyalty, service quality has a positive and significant effect on customer satisfaction, product quality has a positive and significant effect on customers. satisfaction, and customer satisfaction have a significant positive effect on customer loyalty.(Zulkarnain, 2020)

3. A research journal by Jaka Atmaja at AKOM BSI Jakarta in 2018 with the research title "Service Quality and Customer Satisfaction with Loyalty at Bank BJB". Based on the calculation results, it is known that the variables of Service Quality and Customer Satisfaction have a strong influence on Customer Loyalty. Thus, it can be explained that Service Quality is one of the important factors in determining whether or not customers are satisfied with the service, starting from the loyalty of customers or consumers. So that through the implementation of good service quality, it will encourage customer interest and raise customer loyalty.(Atmaja, 2018)

4. Research conducted by Abdul Razak, Jusbair Baheri, and Muhammad Irsyad Ramadhan: 2018 with the title "The Effect of Satisfaction and Trust on Customer Loyalty at Bank Negara Indonesia (BNI) Kendari Branch". The results showed that: (1). Simultaneously, satisfaction and trust have a positive and significant impact on customer loyalty, (2). Some satisfaction has a positive and not significant effect on customer loyalty and (3). Partially trust has a positive and significant impact on customer loyalty.(RAZAK, 2018) 
5. Research journal by Rizal Zulkarnain, HER Taufik, Agus David Ramdansyah: 2020 at the Faculty of Economics and Business, University of Banten Jaya-Serang City with the title "The Effect of Service Quality and Product Quality on Customer Loyalty with Customer Satisfaction as an Intervening Variable (Case Study at PT Bank Syariah Mu'amalah Cilegon)". Based on the results of the study indicate that service quality has a positive and significant effect on customer loyalty, product quality has a positive and significant effect on customer loyalty, service quality has a positive and significant effect on customer satisfaction, product quality has a positive and significant effect on customers. satisfaction, and customer satisfaction have a significant positive effect on customer loyalty.(Zulkarnain, 2020)

6. A research journal by Jaka Atmaja at AKOM BSI Jakarta in 2018 with the research title "Service Quality and Customer Satisfaction with Loyalty at Bank BJB". Based on the calculation results, it is known that the variables of Service Quality and Customer Satisfaction have a strong influence on Customer Loyalty. Thus, it can be explained that Service Quality is one of the important factors in determining whether or not customers are satisfied with the service, starting from the loyalty of customers or consumers. So that through the implementation of good service quality, it will encourage customer interest and raise customer loyalty.(Atmaja, 2018)

\subsection{Research Framework}

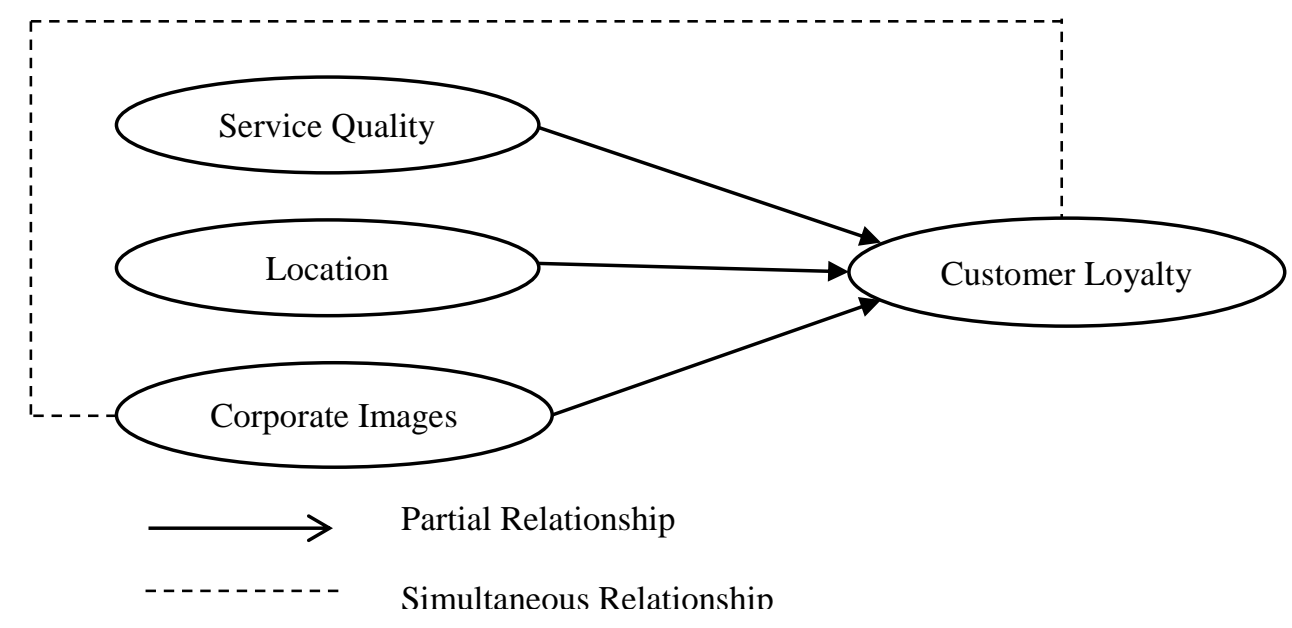

\subsection{Hypothesis}

H1: service quality (x1) has a positive effect on customer loyalty (y).

$\mathrm{H} 2$ : corporate image (x2) has a positive and significant effect on customer loyalty (y).

$\mathrm{H} 2$ : location factor ( $\mathrm{x} 3$ ) has a positive and significant effect on customer loyalty (y).

H4: service quality (x1), company image (x2) and location (x3) simultaneously have significant effect on customer loyalty (y).

\section{Methodology}

\subsection{Research Approach}

In this study, the author uses a quantitative research approach where this method relies on objective measurements and mathematical analysis (statistics) on a sample of data obtained through questionnaires, opinions from various reliable sources, theses, or references from previous research to prove or test the hypothesis provisional conjecture proposed in this study (Gamal Thabroni, 2021).

\subsection{Location And Time Of Research}

This research was conducted. The location of this research is located at Bank Jatim Main Branch Surabaya Jl. Basuki Rakhmad 98-104 Surabaya. Meanwhile, the time for conducting field research, namely distributing questionnaires, is planned to be carried out in June - early July 2021. Meanwhile, the overall time for this research from proposal writing to thesis report preparation is from March - July 2021. The details of the overall research plan are explained in the table below.

\subsection{Population and sample}

a. Population

The population is a generalization area consisting of objects/subjects that have certain quantities and characteristics set by the researcher to be studied and then draw conclusions (Siyoto \& Sodik, 2015). 
The population of this study uses Bank Jatim Main Branch Surabaya customers with a population of more than 23,000 customers. (Darmawan, 2018)

b. Sample

The sampling technique used in this study is a probability sampling technique of simple random sampling or random samples. Probability sampling is a sampling technique that gives each respondent equal rights to be selected as sample members (Sugiyono, 2012). Meanwhile, simple random sampling means that each population has the right to be a respondent or sample regardless of the strata of the respondent (Sugiyono, 2012). The sample of this research is the customer of Bank Jatim Main Branch Surabaya.

\subsection{Definition of operational Variables}

Tabel 1. Definition of Operational Variables

\begin{tabular}{|c|c|c|}
\hline Variable & Indicator & Items \\
\hline $\begin{array}{l}\text { Service } \\
\text { Quality } \\
\text { (X1) }\end{array}$ & $\begin{array}{ll}\text { 1. } & \text { Tangible } \\
\text { 2. } & \text { Reliability } \\
\text { 3. Responsiveness } \\
\text { 4. Assurance } \\
\text { 5. Empathy } \\
\text { (Harfika dan Abdullah, 2017, p. } \\
\text { 48) }\end{array}$ & $\begin{array}{ll}\text { 1. } & \text { Environmental comfort } \\
\text { 2. } & \text { Ability to solve problems } \\
\text { 3. } & \text { Employee response } \\
\text { 4. } & \text { Service security } \\
\text { 5. } & \text { Understanding the masses }\end{array}$ \\
\hline $\begin{array}{l}\text { Company } \\
\text { Images } \\
\text { (X2) }\end{array}$ & $\begin{array}{l}\text { 1. Personality, } \\
\text { 2. Reputation } \\
\text { 3. Value (Nilai-nilai) } \\
\text { 4. Corporate Identity } \\
\text { Harrison (dalam Roy Parto Purba, } \\
\text { 2017) }\end{array}$ & $\begin{array}{l}\text { 1. Employee responsibilities. } \\
\text { 2. Good reputation } \\
\text { 3. More value for the companyab } \\
\text { 4. Company identity }\end{array}$ \\
\hline $\begin{array}{l}\text { Location } \\
\text { (X3) }\end{array}$ & $\begin{array}{l}\text { 1. Location Access } \\
\text { 2. Location Visibility } \\
\text { 3. Traffic } \\
\text { 4. Parking Lot } \\
\text { 5. Expansion. } \\
\text { 6. Environment The area } \\
\text { around the location } \\
\text { 7. Competition Places around } \\
\text { Fatihudin dan Firmansyah } \\
\text { (2019) }\end{array}$ & $\begin{array}{l}\text { 1. Easy to reach } \\
\text { 2. Location is easy to see } \\
\text { 3. Activity density } \\
\text { 4. Land availability } \\
\text { 5. Availability of other places } \\
\text { 6. Safe and comfortable banking } \\
\text { environment. } \\
\text { 7. Able to provide good service } \\
\text { quality }\end{array}$ \\
\hline $\begin{array}{l}\text { Customer } \\
\text { Loyalty } \\
\text { (X4) }\end{array}$ & $\begin{array}{l}\text { 1. Repeat purchase (loyalty to } \\
\text { product purchases) } \\
\text { 2. Retention (resistance to } \\
\text { negative influences on the } \\
\text { company) } \\
\text { 3. Referalls (referring the total } \\
\text { existence of the company) } \\
\text { Kotler (2014) }\end{array}$ & $\begin{array}{l}\text { 1. Use/purchase } \\
\text { 2. Using the services of the same } \\
\text { company } \\
\text { 3. Recommend to others }\end{array}$ \\
\hline
\end{tabular}

\subsection{Data Collection Techniques}

Data collection techniques in this study used the distribution of questionnaires. In the opinion of Sugiyono, (2013: 142) "Questionnaire is a data collection technique that is carried out by giving a set of questions or written statements to respondents to answer".

\subsection{Types and Sources of data}

In this study using quantitative data because in data collection researchers distributed questionnaires to respondents online via google form, namely to customers who were conducting transactions at Bank Jatim Main Branch Surabaya. In this study, data were obtained from customer respondents who were conducting transactions at Bank Jatim Main Branch Surabaya. 
3.7 Types of measuring scale

The type of measurement scale used in this study is the Likert Scale. Based on the opinion of Sugiyono, (2013: 93) "The Likert scale is used to measure attitudes, opinions, and perceptions of a person or group of people about social phenomena". The size of the Likert scale is described as follows:

Example of a Measurement Scale:

\begin{tabular}{lcccc}
\hline \multicolumn{5}{c}{ Measuring Scale } \\
\hline SS (5) & ST (4) & CS (3) & TS (2) & STS (1) \\
& $\checkmark$ & & \\
& & & \\
\hline
\end{tabular}

\subsection{Data Analysis}

Data analysis is an activity after data from all respondents or other data sources are collected. Activities in data analysis are: grouping data based on variables and types of respondents, tabulating data based on variables from all respondents, presenting data for each variable studied, performing calculations to answer the problem formulation, and performing calculations to test the hypotheses that have been proposed. In general, in this study, data analysis uses Multiple Linear Regression (RLB) and uses SPSS version 25 for windows statistical analysis tools.

\section{Validity and reliability test}

a. Uji validitas

If $r$ count $r$ table, the instrument/question item is considered to have a significant correlation with the total score or is considered valid. However, if $\mathrm{r}$ count $<\mathrm{r}$ table then the correlation is considered low or invalid (Marzuki et al., 2020: 62)

b. Uji reliabilitas

According to Pramesti, (2014: 44) "an instrument can be said to be reliable if the Cronbach's Alpha

2. Classical Assumtion Test coefficient is above 0.6 , so it can be said that the instrument has high reliability".

According to Purnomo, (2017: 107) "the classical assumption test is used to determine whether there is residual normality, multicollinearity, autocorrelation, and heteroscedasticity in the regression model.

a. Normality test

The normality test in this study was carried out using the Kolmogorov-Smirnov analysis method. According to (Dahlan (2017) in Hulu \& Sinaga, (2019: 38) the assumption of using the KolmogorovSmirnov analysis can be used "if $\mathrm{p}>0.05$ significance level with a sample size $>50$ "

b. Multicollinearity test

According to Santoso, (2019: 195) this Multicollinearity Test is a test "to find out whether in the regression model there is a correlation between independent variables. If there is a correlation, it is called a multicollinearity (Multiko) problem.

Guidelines for Multicollinearity Decisions according to Priyatna, (2020: 53) are to look at the Tolerance and Variance Inflating Factor (VIF) values:

Guidelines for decisions based on tolerance values:

If the Tolerance value $>0.10$; there is no multicollinearity

If the Tolerance value $<0.10$; multicollinearity occurs

Decision guidelines based on the value of the variance inflating factor (vif):

If the value of VIF $<10.00$; there is no multicollinearity

If the VIF value $>0.10$; multicollinearity occurs

c. Heteroscedasticity test.

According to Gunawan (2020: 128) this Heteroscedasticity Test is a test to assess "whether in the regression model there is an inequality of variance from the residuals from one observation to another observation"

3. Hypothesis testing (parametric and non-parametric statistics)

a. T Test (patrial)

The t-test according to Sugiyono (2014) in Yusuf \& Daris, (2019:134) is a "partial regression coefficient test which aims to determine the significance of the partial role between the independent variables on the dependent variable by assuming that other dependent variables are considered constant". In this study, the test was carried out through the t-test with a $95 \%$ confidence level.

b. F test (simultaneous)

The $\mathrm{f}$ test is a test to determine the effect of the independent variable (X) together (simultaneously) on the dependent variable (Y) (Mulyono, 2018: 113). 
The F-Test Assessment Criteria according to Mulyono, (2018: 113):

- $\mathrm{H} 0$ is accepted, if $\mathrm{F}$ count $\mathrm{F}$ table or sig value $>0.05$

- $\mathrm{H} 0$ is rejected, if $\mathrm{F}$ count $\mathrm{F}$ table or sig value $<0.05$

\section{Test the coefficient of determination ( $(r 2)$}

According to (Ghozali (2007) in Mulyono, (2018:112) The coefficient of determination test essentially measures how much the independent variable is able to explain the dependent variable. The value of the coefficient of determination ranges from 0 to 1 ( 0 R2 1) or from $0 \%$ to $100 \%$. The higher the value of R2 or the coefficient of determination, the higher the ability of the regression model to explain the diversity in the sample data (Susanti et al., 2019:53).

\section{Results and Discussion}

\subsection{Validity Test}

Tabel 2. Validity Test

\begin{tabular}{|c|c|c|c|c|}
\hline Variables & & r-table & r-count & Decision \\
\hline \multirow{6}{*}{$\begin{array}{l}\text { Service Quality } \\
\text { (X1) }\end{array}$} & 1 & 0.189 & 0.648 & valid \\
\hline & 2 & 0.189 & 0.706 & valid \\
\hline & 3 & 0.189 & 0.685 & valid \\
\hline & 4 & 0.189 & 0.614 & valid \\
\hline & 5 & 0.189 & 0.647 & valid \\
\hline & 6 & 0.189 & 0.697 & valid \\
\hline \multirow{5}{*}{$\begin{array}{l}\text { Company } \\
\text { Images (X2) }\end{array}$} & 1 & 0.189 & 0.672 & valid \\
\hline & 2 & 0.189 & 0.640 & valid \\
\hline & 3 & 0.189 & 0.585 & valid \\
\hline & 4 & 0.189 & 0.693 & valid \\
\hline & 5 & 0.189 & 0.656 & valid \\
\hline \multirow[t]{6}{*}{ Location (X3) } & 1 & 0.189 & 0.772 & valid \\
\hline & 2 & 0.189 & 0.759 & valid \\
\hline & 3 & 0.189 & 0.698 & valid \\
\hline & 4 & 0.189 & 0.786 & valid \\
\hline & 5 & 0.189 & 0.762 & valid \\
\hline & 6 & 0.189 & 0.806 & valid \\
\hline \multirow{4}{*}{$\begin{array}{l}\text { Customer } \\
\text { Loyalti (Y) }\end{array}$} & 1 & 0.189 & 0.694 & valid \\
\hline & 2 & 0.189 & 0.740 & valid \\
\hline & 3 & 0.189 & 0.777 & valid \\
\hline & 4 & 0.189 & 0.795 & valid \\
\hline
\end{tabular}


Based on table 2 the results of the validity test above, it shows that the variables of service quality, company image, and customer loyalty are declared valid. This can be seen from the calculated $r$ value $>$ the $r$ table value and the significance is less than 0.05 .

\subsection{Reliable Test}

Tabel 3. Reliable Test

\section{Reliability Statistics}

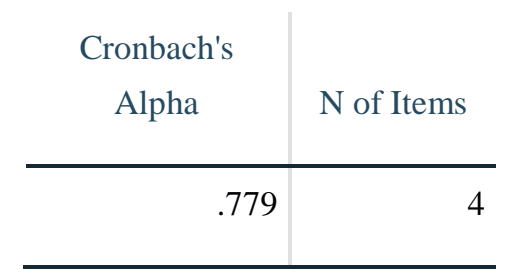

Based on the table above, it can be seen that the Cronbach's Alpha value obtained is greater than 0.6. This shows that the statement items used in this study are stated to be reliable.

\subsection{Normality Test}

Tabel 4. Normality Test

\begin{tabular}{cc}
\hline One-Sample Kolmogorov-Smirnov Test & \\
\hline & Unstandardized \\
& Residual
\end{tabular}

$\mathrm{N}$

Normal Parameters ${ }^{\mathrm{a}, \mathrm{b}} \quad$ Mean

.0000000

Std. Deviation

1.87783157

Most Extreme Differences Absolute

Positive

Negative

Test Statistic

Asymp. Sig. (2-tailed)

$.004^{\mathrm{c}}$

Monte Carlo Sig. (2-tailed) Sig.

From the picture above shows the output of the Kolmogorov-Smirnov One-Sample normality test with the Monte Carlo approach above, it can be seen that the significance value is $0.158>0.05$. Thus it can be concluded that the data used is normally distributed so that it meets the requirements of simple linear regression testing. 


\section{JURNAL EKONOMI}

\subsection{Multicollinearity Test}

Tabel 5. Multicollinearty Test

Coefficients $^{\mathrm{a}}$

\begin{tabular}{lcc}
\hline \multicolumn{2}{c}{ Collinearity Statistics } \\
Independent Variable & Tolerance & VIF \\
\hline Service Quality (X1) & 0.807 & 1,238 \\
Company Image (X2) & 0.808 & 1.238 \\
Location (X3) & 0.925 & 1.081 \\
\hline
\end{tabular}

From the table above, the tolerance value for the independent variable is $>0.1$ and the VIF is smaller than 10. This value indicates that there is no multicollinearity between the independent variables.

\subsection{Heteroskedasticity Test}

Tabel 6. Heteroskedasticity Test

$$
\text { Coefficient }^{\mathrm{a}}
$$

\begin{tabular}{llc}
\hline & Model & Sig. \\
\hline 1 & (Constant) & 0.089 \\
& $\begin{array}{c}\text { Service } \\
\text { Quality } \\
\text { Company } \\
\text { Image } \\
\text { Location }\end{array}$ & 0.108 \\
\hline
\end{tabular}

a. Dependent Variable: Customer Loyality

From the picture above it can be concluded that the value of sig. variables (X1), (X2) and (X3) > 0.05 so there is no heteroscedasticity.

\subsection{T Test}

Tabel 7. T Test

\begin{tabular}{lcc}
\hline \multicolumn{1}{c}{ Variable } & t-Test & t-Table \\
\hline Service Quality & $\mathbf{2 , 0 6 3}$ & $\mathbf{1 , 9 8 5}$ \\
Company Images & $\mathbf{2 , 6 2 5}$ & $\mathbf{1 , 9 8 5}$ \\
Location & $\mathbf{4 , 0 8 5}$ & $\mathbf{1 , 9 8 5}$ \\
\hline
\end{tabular}

From the table above, it can be concluded that the variables of Service Quality, Company Image and location have a significant positive effect on the Customer Loyalty variable with the assumption that $\mathrm{t}$ count $>\mathrm{t}$ table. 


\section{JURNAL EKONOMI}

\subsection{F Test}

Tabel 8. Anova

\begin{tabular}{|c|c|c|c|c|c|c|}
\hline \multicolumn{7}{|c|}{ ANOVA $^{a}$} \\
\hline Model & & $\begin{array}{l}\text { Sum of } \\
\text { Squares }\end{array}$ & $\mathrm{df}$ & Mean Square & $\mathrm{F}$ & Sig. \\
\hline \multirow[t]{3}{*}{1} & Regression & 173.341 & 3 & 57.780 & 15.889 & $.000^{\mathrm{b}}$ \\
\hline & Residual & 349.099 & 96 & 3.636 & & \\
\hline & Total & 522.440 & 99 & & & \\
\hline
\end{tabular}

Based on the ANOVA table above, it is known that the service quality variable (X1), company image (X2), location (X3) has an F value of 15,889 with a value of sig $=0.000$ which shows it is smaller than the value of $=0.050(0.000<0.050)$ which means that the variable service quality $(\mathrm{X} 1)$, company image $(\mathrm{X} 2)$, location (X3) simultaneously have a significant effect on service quality.

\subsection{Coefficient Test of determination $\mathrm{R} 2$}

Tabel 9. Coefficient Test of Determination R2

\begin{tabular}{|c|c|c|c|c|}
\hline \multicolumn{5}{|c|}{ Model Summary } \\
\hline Model & $\mathbf{R}$ & R Square & Adjusted R Square & Std Error the Estimate \\
\hline $\mathbf{1}$ & $576^{2}$ & 0.332 & 0.311 & 1,907 \\
\hline
\end{tabular}

The results of the adjusted $\mathrm{R}$ square calculation in this study are 0.332 , this shows that the value of the coefficient of determination contained in the adjusted $\mathrm{r}$ square value is 0.332 . This means that the ability of the independent variables simultaneously (X1, X2 and X3) in explaining the dependent variable (Y) is $32.2 \%$ so that the remaining $67.8 \%$ can be explained through variables outside this study.

The research shows that the variables of service quality and company image have a positive and significant effect simultaneously or together on customer loyalty. This is evidenced by the calculated $F$ value of $144.187>$ from the F table of 3.090 and a significant value of 0.000 . So this study proves the hypothesis that service quality and company image have a positive and significant effect simultaneously or together on customer loyalty at Bank Jatim Jombang. The value of Adjusted R Square in this study has a value of 0.743 which means that the influence of service quality and company image variables on customer loyalty at Bank Jatim Jombang is $74.3 \%$, while the remaining $25.7 \%$ is influenced by other variables not mentioned in this study.

\section{Conclusions and Suggestions}

\subsection{Conclusion}

1. Service quality partially has a significant positive effect on customer loyalty variables.

2. Company image partially has a significant positive effect on customer loyalty variables.

3. Location has a significant positive partial effect on the Customer Loyalty variable.

4. Service Quality (X1), Company Image (X2), Location (X3) simultaneously have a significant effect on Service Quality.

\subsection{Suggestions}

1. The results of the study indicate that there is a positive influence of Service Quality, Company Image and Location on Customer Loyalty, so that companies must as much as possible maintain and continue 


\section{JURNAL EKONOMI}

to develop in terms of service quality, corporate image, and optimize existing locations. In this case the company must continue to have new innovations to strengthen it.

2. For further research, other variables can be used that can affect Customer Loyalty in their research and this research can be used as a reference.

\section{References}

Atmaja, J. (2018). Kualitas Pelayanan dan Kepuasan Nasabah Terhadap Loyalitas Pada Bank BJB. Jurnal Ecodemica, 2(1), 49-63. https://ejournal.bsi.ac.id/ejurnal/index.php/ecodemica/article/view/2713

Batin, M. H. (2020). Pengaruh Citra Bank, Kualitas Pelayanan, Kepercayaan Nasabah, Penanganan Keluhan, Dan Kepuasan Terhadap Loyalitas Nasabah Pada Bank Sumsel Babel Kantor Capem Syariah UIN Raden Fatah Palembang. MALIA: Journal of Islamic Banking and Finance, 3(1), 45. https://doi.org/10.21043/malia.v3i1.5600

Darmawan, D. (2018). The Effect of Service Quality, Customer Satisfaction and Corporate Image on Customer Loyalty in the banking sector in Indonesia. 19(11), 46-51. https://doi.org/10.31219/osf.io/uxsfr

Gamal Thabroni. (2021). Pengertian Metode Penelitian Kuantitatif. Serupa.Id. https://serupa.id/metodepenelitian-kuantitatif-pengertian-karakteristik-jenis/

RAZAK, A. (2018). Pengaruh Kepuasan Dan Kepercayaan Terhadap Loyalitas Nasabah Pada Bank Negara Indonesia (Bni) Cabang Kendari. Journal of Economic and Business, 2(79), 227-249.

Sharah, N. M., Kusumawati, Y. T., \& Timur, M. K. (2021). Analisis Pengaruh Kualitas Pelayanan dan Lokasi Bank Terhadap Kepuasan Nasabah Bank Kaltimtara di Samarinda 2020 - 2021. 2(2), 1503-1509.

Yolanda, \& Firdaus, D. (2019). PENGARUH KUALITAS PELAYANAN DAN PROMOSI TERHADAP CITRA PERUSAHAAN SERTA DAMPAKNYA PADA KEPUTUSAN NASABAH MENABUNG (Studi Kasus Pada Bank BRI Kantor Cabang Pembantu Meester). Jurnal Manajemen, 07(1), 118-140.

Zulkarnain, R. (2020). Pengaruh Kualitas Pelayanan dan Kualitas Produk terhadap Loyalitas Nasabah dengan Kepuasan Nasabah sebagai Variabel Intervening. Jurnal Manajemen Dan Bisnis, 1-24. 